HARRIS, L. D. (1972). An ecological description of a semi-arid East African ecosystem. Range Science: Department Science Series No. 21, Colorado State University, pp. $80+$ illustr.

Hillman, J. C. \& Hillman, A. K. K. (1977). Mortality of wildlife in Nairobi National Park, during the drought of 1973-1974. East Afr. Wildl. J., 15, pp. 1-18.

Hooper, M. D. (1971). The size and surroundings of nature reserves. Pp. 555-61 in The Scientific Management of Animal and Plant Communities for Conservation (Ed. E. Duffy \& A. S. Watt). Blackwell, Oxford, England: $\mathrm{xvi}+652 \mathrm{pp}$.

LAMPREY, H. F. (1963). Ecological separation of the large mammal species in the Tarangira Game Reserve, Tanganyika. East Afr. Wildl. J., 1, pp. 63-92.

LAMPREY, H. F. (1972). Management of flora and fauna in National Parks. Pp. 237-48 in Second World Conference on National Parks (Ed. Sir Hugh Elliott). IUCN publications, Morges, Switzerland: 504 pp.

LAws, R. M. (1970). Elephants as agents of habitat and landscape change in East Africa. Oikos, 21, pp. 1-15.

MAY, R. M. (1975a). Island biogeography and the design of wildlife preserves. Nature (London), 257, pp. 177-8.

MAY, R. M. (1975b). Patterns of species abundance and diversity. Pp. 81-120 in Ecology and Evolution of Communities (Ed. M. L. Cody \& J. M. Diamond). Harvard University Press, Cambridge, Mass.: xii +545 pp., illustr.

MacArthur, R. H. \& Wilson, E. O. (1967). The Theory of Island Biogeography. Princeton University Press, Princeton, N.J.: 203 pp. + illustr.

MCCLintock, L., Whitcomb, R. F. \& WhitcomB, B. L. (1977). Island biogeography and habitat islands of eastern forest, II: Evidence for the value of corridors and minimization of isolation in preservation of biotic diversity. Amer. Birds, 31(1), pp. 6-16.

Miller, R. I. \& HaRRIS, L. D. (1977). Isolation and extirpations in wildlife reserves. Biol. Conserv., 12, pp. 311-6.

Miller, R. I. \& Harris L. D. (in press). Predicting species changes in isolated wildlife preserves. In Proceedings of the First Conference on Scientific Research in the National Parks, New Orleans, Louisiana, 1976.

Moore, N. W. \& HoOper, M. D. (1975). On the number of bird species in British woods. Biol. Conserv., 8, pp. 238-50.

Odum, E. P. (1969). The strategy of ecosystem development. Science, 164, pp. 262-70.
Preston, F. W. (1962). The canonical distribution of commonness and rarity. Ecology, 43, pp. 185-215 \& 410-32.

Root, R. H. (1973). Organization of a plant-arthropod association in simple and diverse habitats: the fauna of Collards (Brassica oleracea). Ecol. Monogr., 43, pp. 95-124.

SimberLoFF, D. S. (1976). Experimental zoogeography of islands: effects of island size. Ecology, 57, pp. 629-42.

Simberloff, D. S. \& Abele, L. G. (1976). Island biogeography theory and conservation practice. Science, 191, pp. 285-6.

Simberloff, D. S. \& Wilson, E. O. (1969). Experimental zoogeography of islands: the colonization of empty islands. Ecology, 50, pp. 278-96.

SlayTER, E. O. (1975). Ecological reserves: size, structure and management. Pp. 22-38 in A National System of Ecological Reserves in Australiia (Ed. F. Fenner). Austr. Acad. Sci., Canberra, Australia: 114 pp. + illustr.

Sullivan, A. L. \& Shaffer, M. L. (1975). Biogeography of the megazoo. Science, 189, pp. 13-7.

Terborgh, J. (1974a). Preservation of natural diversity: the problem of extinction-prone species. BioScience, 24(12), pp. 715-22.

TERBorgh, J. (1974b). Faunal equilibria and the design of wildlife preserves. Pp. 369-80 in Tropical Ecological Systems (Ed. F. B. Golley \& E. Medina). Springer-Verlag, New York, N.Y.: xiii +398 pp., illustr.

USHER, M. B. (1973). Biological Management and Conservation: Ecological Theory, Application and Planning. Chapman \& Hall, London, England: xi + 394 pp., illustr.

WARD, L. K. \& LAKHANI, K. H. (1977). The conservation of Juniper: the fauna of food-plant island sites in southern England. J. Appl. Ecol., 14, pp. 121-35.

Whitcomb, R. F., Lynch, J. F., Opler, P. A. \& Robins, C. S. (1976). Island biogeography and conservation: strategy and limitations. Science, 193, pp. 1,030-2.

Willis, E. O. (1974). Populations and local extinction of birds on Barro Colorado Island, Panama. Ecol. Monogr., 44, pp. 153-69.

WILlis, J. C. (1922). Age and Area. Cambridge University Press, Cambridge, England: pp. 259 + illustr.

Wilson, E. O. \& Willis, E. O. (1975). Applied biogeography. Pp. 522-36 in Ecology and Evolution of Communities (Ed. M. L. Cody \& J. M. Diamond). Harvard University Press, Cambridge, Mass.: xii + 545 pp., illustr.

\title{
Kenya's Elephant Population Halved by Poachers Since 1973
}

The elephant population of Kenya has been reduced to less than half by poaching since 1973, according to a report received by the World Wildlife Fund. The present elephant population of the country is put at between 65,000 and 75,000 , following a study carried out in Kenya as part of a three-years' project for conservation of the world's elephants. This project, jointly financed by the World Wildlife Fund and the New York Zoological Society, aims at establishing a true picture of the elephant situation in Africa and Asia, and at working out effective conservation measures. These should include control of the ivory trade, which is the main threat to the survival of elephants, together with loss of habitat to agriculture and human settlement.

As there is always ivory resulting from the natural deaths of elephants, it is hoped that countries with elephant populations will understand that they have a direct financial interest in conserving them if the trade is properly controlled.

It is estimated by Dr Iain Douglas-Hamilton, leader of the project, that there are at least $1,300,000$ African ele- phants, but they are declining in numbers in almost all of the 30 or so countries where they are still found. The Asiatic elephant is estimated at between 27,000 and 40,000, and is considered seriously threatened.*

A team of scientists and other specialists has been drawing up a draft action plan for 'Elephants and Their Environment', which is based on the fact that the elephant must be regarded as part of its ecosystem, and so conservation of its habitat is the best way of protecting elephants and other species which share that environment.

* See also comments in recent issues of Environmental Conservation, including Vol. 3, No. 4, p. 258, 1976; Vol. 4, No. 1, p. 68,1977 ; Vol. 4 , No. 3 , p. 236,1977 ; and Vol. 5, No. 2, p. $146,1978 .-$ Ed.

PeTER F. R. JACKSON, Director of Information World Wildlife Fund

1110 Morges

Switzerland. 